\title{
PHYSIOLOGICAL AND BIOCHEMICAL EFFECT OF FUNGUS BEAUVERIA BASSIANA ON THE ADULT FEMALE OF SPIDER MITE, TETRANYCHUS URTICAE (KOCH)
}

\author{
MIKHAIL, W.A. ${ }^{1}$; H.M. SOBHY ${ }^{1}$; MAHA S. NADA ${ }^{2}$; M.E.EL-NAGGAR ${ }^{2}$ and \\ RANIA. H. MAHMOUD ${ }^{2}$
}

1. Natural Resources Dept. , Inst. African Research \& Studies, Cairo Univ., Egypt.

2. Plant Protection Research Institute, ARC, Egypt.

(Manuscript received 6 July 2015)

\begin{abstract}
$\mathrm{T}$ he two-spotted spider mite Tetranychus urticae is considered to be one of the most economically important pests, since it infests over 200 species of plants (Johnson 1991). Beauveria bassiana is highly control agent to this mite ,and affects its mortality ,biochemistry and physiolology. To test this effect ,the B. bassiana was applied at $10^{5}$ spores / $\mathrm{ml}$ using dipping leaf -disc treatment method. Mortality, total proteins, carbohydrates and lipids of mite were measured; Mites adult females were susceptible to $B$. bassiana, with high mortality rate recorded. The effect of $B$. bassiana on proteins level in the mycosed extract homogenate appeared decreasing than the nonmycosed during the period of experiment. The means of total protiens are 225,220 and $183 \mu \mathrm{g} / \mathrm{ml}$ after 24,48 and $72 \mathrm{hrs}$ respectively,compared with $327 \mu \mathrm{g} / 1000$ individuals in untreated control. Effect of the $B$. bassiana on the level of the carbohydrates decreased in the treated extract homogenate than the untreated one during the period of experiment. The mean of total carbohydrates at 24,48 and $72 \mathrm{hrs}$ after treatment were 142,138 and $115 \mu \mathrm{g} / \mathrm{ml}$ respectively, compared with $149 \mu \mathrm{g} / 1000 \mathrm{ml}$, In untreated control. The effect of $B$. bassiana on lipids level in treated extract homogenate appeared decreasing than in untreated one during the period of experiment. The obtained result refer to the mean total lipids were 92,77 , and $70 \mu \mathrm{g} / \mathrm{ml}$ after 24,48 and 72 hrs, respectively compared with $88 \mu \mathrm{g} / 1000$ individuals untreated adult females of $T$. urticae. This study improves that entomopathogenic fungus $B$. bassiana causes many biochemical and physiological changes in the mite Tetranychus urticae. $B$. bassiana is also considered as a safe biological control agent to the environment.
\end{abstract}

Key words: fungus, Beauveria bassiana, mite, Tetranychus urticae, physiology, biochemistry, biological control.

\section{INTRODUCTION}

Many species of spider mites especially of the genus Tetranychus are of economic importance in many regions of the world. Tetranychus urticae (Koch), the two-spotted spider mite, infests over 200 plant species worldwide (Johnson 1991). 
This species $T$. urticae, has been known as a worldwide pest of a wide range of horticultural crops both outdoors and in the green houses.

Fungi pathogen to mites play an important role in the regulation of natural mite population, and are sometimes able to decimate populations of phytophagous mite (Van der Geest et al. 2000).

Scientists all over the world have a growing interest in reducing dependence on chemical pesticides as means of controlling pests. Natural antagonists are considered most promising biological mean of pest control such as entomopathogenic fungi (Hassan 2003).

Shi and Feng (2004) reported that some of the tested isolates of Beauveria bassiana, Metarihizium anisopliae or Paecilomyces fumosorseus are highly effective to the eggs and females of Tetranychus cinnabarinus. Chandler et al. (2000) reviewed opportunities of exploiting fungal pathogens for biological control of Acari, including mites.

This study aims to evaluate the mortality rate, biochemical and physiological changes in the $T$. urticae (Koch) after exposed to fungus B. bassiana. Contributing to a better biological understanding and development of the new technique for microbial control.

\section{MATERIALS AND METHODS}

\section{Rearing of $T$. urticae}

The original colony of the two-spotted spider mite. T. urticae in this study was supplied from Acarology laboratory at Plant Protection Research Institute, A.R.C. Dokki, Giza, Egypt.

It was reared as a test mite for several generations at $25 \pm 1^{\circ} \mathrm{C}$ away from any pesticide contamination. The mite was maintained on detached mulberry leaves with the lower surface upwards placed on moist cotton wool pads in fiber-dishes (20 $\mathrm{cm}$ in diameter). The cotton pads were moistened daily to avoid disc dryness, and the prevent mite escape. Castor bean leaves were changed by fresh one form time to time when necessary (Hassan 2009).

\section{Entomopathogenic Fungi Strains:}

Fungus Beavuveria bassiana (Blas) was used in this study isolated from soil in 1995, at Giza Governorate by Maha Salah El-Din Nada, Researcher, Department of Piercering and Sucking Insect, Plant Protection Research Institute, Dokki Cairo, Egypt. 


\section{Culturing of entomopathogenic fungi :}

Fungus $B$. bassiana was grown using autoclaved Sabouroud Dextrose Agar Yeast media (SDAY (10 g/L peptone $+40 \mathrm{~g} / \mathrm{L}$ Dextrose $+2 \mathrm{~g} / \mathrm{L}$ yeast extract $15 \mathrm{~g} / \mathrm{L} \mathrm{Agar}+1 \mathrm{~L}$. Distilled Water) then incubated at $25 \pm 1^{\circ} \mathrm{C}$ for 10 days. (Devi et al. 2005).

\section{Bioassay procedure:}

Twenty fertilized of mite adult females placed on a single leaf-disc of Castor bean leaves ( $2.5 \mathrm{~cm}$ in diameter) and were kept on moist cotton wool in fiber dishes; each dish contained 5 discs as replicate. The dipping leaf-disc technique was applied. Discs were dip in $2 \mathrm{ml}$ suspension of fungus for $10 \mathrm{sec}$. then left for drying and then adult females were transferred to treatment discs with five concentrations of fungus B. bassiana $10^{6}, 5 \times 10^{6}, 10^{7}, 5 \times 10^{7}$ and $10^{8}$ spores $/ \mathrm{ml}$ and $2 \mathrm{ml}$ sterilized distilled water of $0.1 \%$ Triton-x 100 as control. The treated adult females of mite and control were incubated at $25 \pm 1^{\circ} \mathrm{C}$. Mortality was assessed daily for 7 days. The percentages of mortality were determined and $\mathrm{LC}_{25}, \mathrm{LC}_{50}$ and $\mathrm{LC}_{90}$ values were calculated according to (Finney,1971) .

\section{Biochemical and physiological analysis:}

Spider mites are minute so the number of mite needed in order to study these changes were 1000 adult females placed in a 1.5 microtube.

\section{Characterization of biochemical and physiological changes of adult females after infection with Beauveria bassiana .}

\section{1- Preparation of mites for analysis:}

Mites were prepared as described by (Amin, 1998). They were homogenized in distilled water $(50 \mathrm{mg} / 1 \mathrm{ml})$. Homogenates were centrifuged at 8000 r.p.m. for 15 min at $2^{\circ} \mathrm{C}$ in a refrigerated centrifuge. The deposits were discarded and the supernatants, which is referred as enzyme extract, are stored at least one week without appreciable loss of the enzyme activity when stored at $5^{\circ} \mathrm{C}$.

\section{2- Determination of total proteins}

Total proteins were determined by the method of Bradford (1976). Protein reagent was prepared by dissolving $100 \mathrm{mg}$ of Coomassie Brilliant blue G-250 in $50 \mathrm{ml}$ $95 \%$ ethanol. To this solution , $100 \mathrm{ml}$ of phosphoric acid ( $85 \% \mathrm{w} / \mathrm{v})$ were added. The resulting solution $(50 \mu \mathrm{l})$ or for preparation of standard curve $50 \mu \mathrm{l}$ of serial concentrations containing 10 to $100 \mu \mathrm{g}$ boving serum albumin were pipetted into test tubes the absorbance at $595 \mathrm{~nm}$ was measured after $2 \mathrm{~min}$. and before $1 \mathrm{hr}$ against blank prepared from $1 \mathrm{ml}$ of phosphate buffer and $5 \mathrm{ml}$ protein reagent.

\section{3- Determination of total carbohydrates:}

Total carbohydrates were estimated in acid extract of sample females of $T$. urticae by the phenol-sulfuric acid reaction of Dubois et al., (1956). Total 
carbohydrates were extracted and prepared for assay according to Crompton and Birt (1967). Sample of mites were homogenized in $0.3 \mathrm{HClO} 4(5 \mathrm{ml})$ at $0 \mathrm{C}$ for $1 \mathrm{~min}$. insoluble matter was removed by centrifugation for $3 \mathrm{~min}$. at 2000 r.p.m and washed twice in ice-cold $\mathrm{HClO} 4(5 \mathrm{ml})$ by re-dispersion and centrifugation. Hundred microliters of the acid extract were added into a colorimetric tube to $0.5 \mathrm{ml}$ of phenol then $5 \mathrm{ml}$ of concentrated sulfuric acid were added rapidly with shaking.the tube were allowed to stand $10 \mathrm{~min}$, then they were shaken and placed for $10-20 \mathrm{~min}$. in 25 to $30^{\circ} \mathrm{C}$ before readings. The absorbance of characteristic yellow-orange color is measured by spectrophotometer at $490 \mathrm{~nm}$ against blank. Total carbohydrates expressed as: $\mu \mathrm{g}$ glucose/1000 individuals.

\section{4- Determination of total lipids:}

Total lipids were estimated by the method of Knight. et al. (1972) using phosphovanillin reagent prepared by dissolving of $0.6 \mathrm{mg}$ pure vanillin in $10 \mathrm{ml}$ ethanol and completed to $100 \mathrm{ml}$ with distilled water. Then $400 \mathrm{ml}$ conc. Phosphoric acid were added . $250 \mu \mathrm{l}$ of sample were added to conc. sulphuric acid $(5 \mathrm{ml})$ in a test tube and heated in a boiling water bath for $10 \mathrm{~min}$. After cooling to room temprature, the digestion was added to phosphovanillin reagent $(6 \mathrm{ml})$. The developed color was measured after $45 \mathrm{~min}$, at $525 \mathrm{~nm}$ by spectrophotometer against reagent blank. Optical density was compared to that of a reference standard and results expressed as $\mu \mathrm{g}$ lipids $/ 1000$ individuals.

\section{5- Statistics:}

All experiments were replicated 3 times (mites homogenates), and the results of biochemical determinations were pooled from triplicate determinations. The results were analyzed by one-way analysis of variance (ANOVA) using SAS for regression analysis (SAS Institute,2006) When the ANOVA statistics were significant $(P \leq 0.001)$, means were compared by the Duncan's multiple range test. (1955).

\section{RESULTS AND DISCUSSION}

\section{1-Bioassay procedure:}

Data showed that the mortality rate of the adult females of the red spider mite $T$. urticae infected by $B$. bassiana increased with increasing concentrations of spores suspension. The $\mathrm{LC}_{25}, \mathrm{LC}_{50}$ and $\mathrm{LC}_{90}$ were $10^{5}, 3.03 \times 10^{6}$ and $2.16 \times 10^{9}$ spores/ml, respectively.

\section{2-Biochemical analysis:}

Total proteins, total carbohydrates and total lipids are major biochemical components necessary for an organism development, growth and performance of its 
vital activities, thus the mean value of homogenate contents of carbohydrates, proteins and lipids were estimated in adult females of $T$. urticae treated with $\mathrm{LC}_{25}\left(10^{5}\right.$ spores/ml) of fungus $B$. bassiana after 24,48 and 72 hrs.

\section{a- Total protein:}

Data in Table (1) showed that the mean total protein reached 255, 220, 183 $\mu \mathrm{g} / \mathrm{ml}$ after 24,48 and $72 \mathrm{hrs}$, respectively, compared with $327 \mu \mathrm{g} / \mathrm{ml}$ in untreated control. These results agree with that obtained by Mettaweh et al. (2001) who found that total protein in the haemolymph of treated grasshopper Eurpepocnemis plorans ( $5^{\text {th }}$ instar nymph) decreased than untreated ones.

Gillespie et al. (2000) observed reduction in total proteins content of the haemolymph of adult Schistocereca gregaria during the infection with the Metarihizium anisopliae. The losses of soluble protein from the host haemolymph during parasitism may be due to the fungus may secretes proteolytic enzymes into the haemocoel of the host and hydrolyze the host's proteins. Abd El-Kerim (2002) found a decrease in haemolymph protein in adult desert locust $S$. gregaria 3 days after inoculation with the entomopathogenic fungus, $M$. anisopliae. This study agree with the obtained data in this study.

\section{b- Total carbohydrates:}

The results obtained for total carbohydrates at 24, 48, 72 hrs after treated with $\mathrm{LC}_{25}$ of $B$. bassiana are shown in Table (1). It was obvious that mean total carohydrates were highly reduced after treatment by $\mathrm{LC}_{25}$ of $B$. bassiana after 24 , 48 and $72 \mathrm{hrs}$ were $142,138,115 \mu \mathrm{g} / \mathrm{ml}$ respectively, compared with $149 \mu \mathrm{g} / 1000$ individuals, in untreated control. Our results revealed actual decrease in total carbohydrates contents of infected hosts after $24,48,72$ hrs from infection with $B$. bassiana these results are in agreement with (Wright, et al., 2004).

El-Banna et al. (2012) reported that actual decreased in the total carbohydrates contents of infected $S$. gregaria after $24 \mathrm{hrs}$ from infection with $M$. anisopliae and this agree with our results.

El-Banna et al. (2012) demonstrated that decreasing of the total carbohydrates lead to decreasing in mite fitness after infection with the fungus and may the fungus causes physiological imbalance.

\section{C -Total lipid:}

Data in Table (1) revealed that the mean total lipids were 92, 77 and $70 \mu \mathrm{g} / 1000$ individuals after 24,48 and $72 \mathrm{hrs}$, respectively treatment with $\mathrm{LC}_{25}$ with $B$. bassiana compared with 88 $\mu \mathrm{g} / 1000$ indviduals untreated adult females of $T$. urticae. 
Seyoum et al. (2002) found that mycosed locusts have significantly lower haemolymph lipids and carbohydrates concentrations than the control and the present study agree with.

El- Banna et al. (2012) reported that decreasing in total lipids in $5^{\text {th }}$ instar of S. gregaria infected with $M$. anisopliae and that may due to metabolite depletion by the fungus (parasite) could cause physiological imbalances in the host that lead to changes in enzymes activities and a reduction in hacmolymph protein, carohydrates and lipid contents.

Table 1. The effect of $B$. bassiana $\left(10^{5}\right.$ spores $\left./ \mathrm{ml}\right)$ on total proteins, total carohydrates and total lipids contents in treated adult females of $T$. urticae

\begin{tabular}{|c|c|c|c|}
\hline \multirow{2}{*}{ Time -hours } & Total proteins & Total carbohydrates & Total lipids \\
\cline { 2 - 4 } & \multicolumn{2}{|c|}{ Means \pm SE } & \\
\hline 24 & $255 \pm 24^{\mathrm{b}}$ & $142 \pm 7.5^{\mathrm{ab}}$ & $92 \pm 7^{\mathrm{a}}$ \\
\hline 48 & $220 \pm 23^{\mathrm{c}}$ & $138 \pm 5^{\mathrm{b}}$ & $77 \pm 4^{\mathrm{b}}$ \\
\hline 72 & $183 \pm 11^{\mathrm{d}}$ & $115 \pm 11^{\mathrm{c}}$ & $70 \pm 4^{\mathrm{b}}$ \\
\hline Control & $327 \pm 23^{\mathrm{a}}$ & $149 \pm 14^{\mathrm{a}}$ & $88 \pm 4^{\mathrm{a}}$ \\
\hline L.S.D & 40.107 & 20.3 & 9.75 \\
\hline F & 124.68 & 27.8 & 55.3 \\
\hline
\end{tabular}

Values represent mean of three separated groups $\pm S E, P \leq 0.001$ highly significant

\section{REFERENCES}

1. Abd Al-Kerim, I. A. 2002. Biochemical studies on the desert locust,Schistocereca gregaria after poisning with the insecticide Banacol. Egyptian J. Agric, Res, 80 (4):1613-1621.

2. Amin, T.R. 1998. Biochemical and physiologica studies of some insect growth regulators on the cotton leaf worm, Spodoptera littoralis (Boisd.). Ph.D.Thesis, Fac. Science, Cairo Univ., Egypt.

3. Bradford, M.M. 1976. A rapid and sensitive method for the quantitation of microgram quantities of proteins utilizing the principle of protein-dye binding. Anal. Bochem 72: 248-254.

4. Chandler, D.; Davidson, G.; Pell, J.G.; Ball, B.V.; Shaw, K.; Sunderland, K.D. 2000. Fungal biocontrol of Acari. Biocontrol, Sci., Technol ., 10: 357-384.

5. Crompton, M. and Birt, L.M. 1967. Changes in the amounts of carbohydrates, phosphagen, and related compounds during the metamorphosis of the blow fly, Lucilia cuprina. J. Insect. Physiol., 13: 1575-15795.

6. Devi, U.K.; Sridevi, V.; Murali Mohan, Ch.; Padmavathi, J. 2005. Effect of high temperature and water stress on invitro germination and growth in isolates of the entomopathogenic fungus Beauveria bassiana (Bals.). J. Inverteb. Pathol., 88(3): 181-189. 
7. Dubios, M.; Gilles, K.A.; Hamilton, J.K.; Roberts, P.A.; Smith, F. 1956. Colorimetric method for determination of sugars and related substances. Analyt. Chem. 28: 350-356.

8. Duncan, D.B. 1955. Multiple ranges and multiple F.test.Biometrics,11:1-41.

9. El-Banna,S.M. ; Elhadidy, N.M.; Semida, F.M.; Abdel-Rasool, T. 2012. Physiological and biochemical effect of entomopathogenic fungus Metarihizium anisopliae on the 5th instar of Schistocereca gregaria (Orthoptera: Acrididae). J.Res. Environ. Sci. Toxicol. ,1:7-Finney,D.J.(1971):Probbit Analysis.Cambridge.Univ.Press.

10. Gillespie, J. P.; Burnett, C.; Charnley, A.K. 2000. The immune response of the desert Locust Schistocera gregaria during mycosis of the entomopathogenic fungus, Metarihizium anisapliae var acridum. J. Physiol. 46: 429-437.

11. Hassan, Dalia. M. 2009. Using a biological control method for controlling red spider mite in Egypt and Namibia. M.Sc. Thesis, Instit. of African Reaearch \&studies, Cairo Univ. Egypt: 107 pp.

12. Hassan, Rania. H.M. 2003. Studies on fungal pathogens for controlling the twospotted spider mite Tetranychus urticae (Koch). M.Sc. Thesis, Fac., Agric. Cairo Univ. Egypt: 95 pp.

13. Johnson, W.T.; Lyon, H.H. 1991. Insects that Feed on Trees and Shrubs. $2^{\text {nd }}$ ed.,rev. Comstock Publishing associates.560pp.

14. Knight, J.A.; S. Anderson and J.M. Rawle. 1972. Chemical basis of the sulfophospho-vanillin reaction for estimating total serum lipids: J. Clin. Chem., 18: 199-202.

15. Mettaweh, H.H.; Gomma, E.A.A.; Sherif, R.M.; Abdel-Fattah, T.A. 2001. Three entomofathogenic fungi and their effect on some biological aspects of the grasshopper, Euprepocnemis plorans plorans Charpenter. Orthoptera: Acrididae). Egypt. J. Biol. Pest. Cont., 11(2): 165-175.

16. SAS Institute Inc. 2006. The SAS System for Windows 9.1. SAS Institute, Cary, NC., U.S.A.

17. Seyoum, E.; Bateman, R. P. and Charnley, A. K. 2002. The effect of Metarhizium anisopliae var. acridum on haemolymph energy reserves and flight capability in the desert locust, Schistocerca gregaria .j . Appl. Entomol. , 126: 119-124.

18. Shi, W.B.; Feng, M.G. 2004. Lethal effect of Beauveria bassiana, Metarihizium anisopliae and Paecilomyces fumosoroseus on the eggs of $T$. cinnabbarinus (Acari: Tetranychidae) with adescription of a mite egg bioassay system. Biol. Control 30: 165-173.

19. Van der Geest, L.P.S.; Elliot, S.L. Breeuwer; J.A. and Beerling, E.A.M. 2000. Diseases of mites. Exper. Appl. Acarol . 24(7): 497-560.

20. Wright C.; Brooks A.; Wall, R. 2004. Toxicity of the entomopathogenic fungus Metarihizium anisopliae to adult females of the blowfly Lucilia sericata. School of Biological Science, Bristol Univ., Wood Land, UK, 60(1): 639-644. 


\section{التاثير الفسيولوجي و البيوكيميائي لفطر المسكاردين الابيض على الحلم العنكبوتي ذي البقعتين}

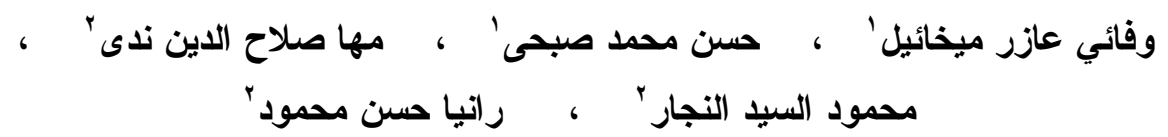

ا ـ قسم الدوارد الطبيعبة (الحبوانية) - معهد البحوث والدراسات و الافريقبة - جامعة القاهرة. r. معهُ بحوث وقاية النباتات- مركز البحوث الزراعية - الدقي - الجبزة.

يعتبر الأكاروس الأخضر ذب البقعتين Tetranychus urticae من أهم انو اع الحلم اقتصاديا، حيث أن هذا الحلم يصيب أكثر من .. ب نوع من النباتات ' كذلك فطر المسكاردين الابيض عامل مكافحة حيوي ذات فاعلية جيدة .

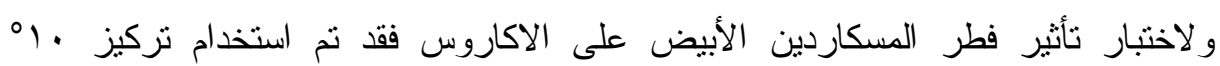
جرثومه/مل وتطبيقه بطريقة الغمر لقرص ورقة نبات التوت و تقدير نسب موت هذا الأكاروس .

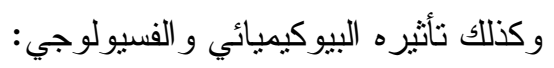

حيث تم تقدير نسبة كلاً من: البروتينات الكلية و الكربو هيدرات الكلية وكذلك اللبيدات الكلية لهذا الاكاروس. و اظهرت النتائج حساسية هذا الاكاروس للفطر و خاصة الاناث البالغة حيث سجلت

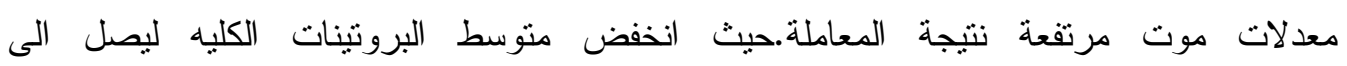

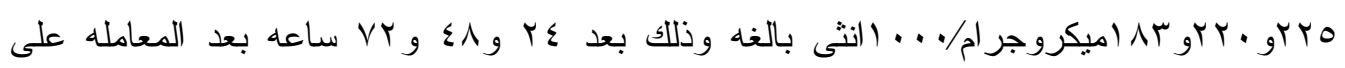

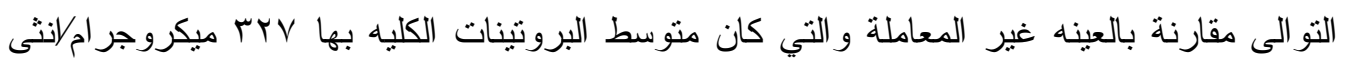
بالغه.

وكان تاثير الفطر ايضا سلبيا مما ادى لانخفاض كمية الكربوهيدرات في المستخلص

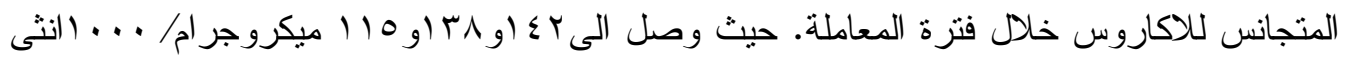

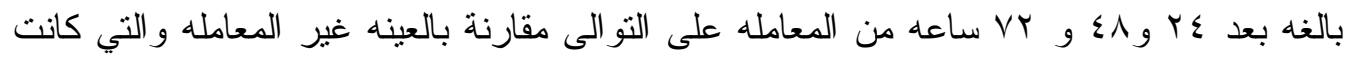

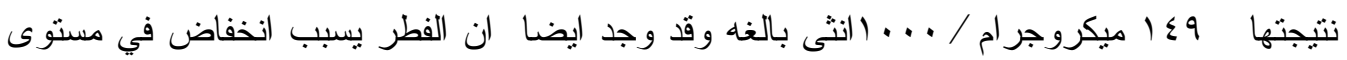

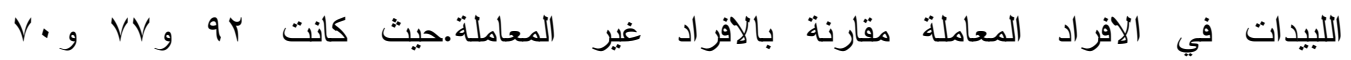

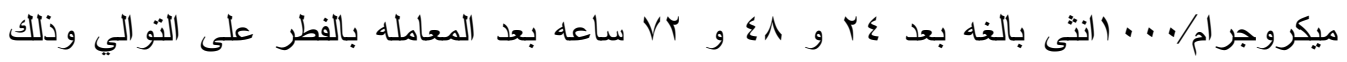

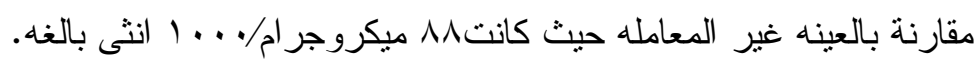

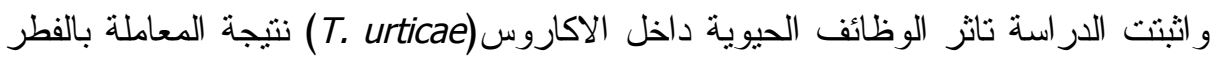
مما يجعله احد عناصر المكافحه الحيوية و الامنة على البيئة. 